\title{
The enigmatic ichnofossil Tisoa siphonalis and widespread authigenic seep carbonate formation during the Late Pliensbachian in southern France
}

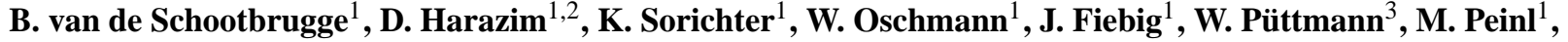 \\ F. Zanella ${ }^{4}$, B. M. A. Teichert ${ }^{5}$, J. Hoffmann ${ }^{1}$, A. Stadnitskaia ${ }^{6}$, and Y. Rosenthal ${ }^{7}$ \\ ${ }^{1}$ Institute of Geosciences, Goethe University Frankfurt, Altenhöferallee 1, 60438 Frankfurt am Main, Germany \\ ${ }^{2}$ Department of Earth Sciences, Memorial University of Newfoundland, St. John's, NL A1B 3X5, Canada \\ ${ }^{3}$ Institute of Atmospheric and Environmental Sciences, Goethe University Frankfurt, Altenhöferallee 1, 60438 Frankfurt am \\ Main, Germany \\ ${ }^{4}$ Institute of Neuroradiology, Goethe University Frankfurt, Schleusenweg 2-16, 60528 Frankfurt am Main, Germany \\ ${ }^{5}$ Institute of Geology and Paleontology, University of Münster, Corrensstraße 24, 48149 Münster, Germany \\ ${ }^{6}$ Royal Netherlands Institute for Sea Research, Landsdiep 4, 1797 SZ 't Horntje (Texel), The Netherlands \\ ${ }^{7}$ Institute of Marine and Coastal Sciences, Rutgers University, 71 Dudley Road, New Brunswick, USA
}

Received: 29 April 2010 - Published in Biogeosciences Discuss.: 4 June 2010

Revised: 23 September 2010 - Accepted: 29 September 2010 - Published: 13 October 2010

\begin{abstract}
Tubular carbonate concretions of up to $1 \mathrm{~m}$ in length and perpendicular to bedding, occur abundantly in the Upper Pliensbachian (upper Amaltheus margaritatus Zone, Gibbosus Subzone) in outcrops (Fontaneilles section) in the vicinity of Rivière-sûr-Tarn, southern France. Stable isotope analyses of these concretions show negative $\delta^{13} \mathrm{C}$ values that decrease from the rim to the center from $-18.8 \%$ o to $-25.7 \%$ o (V-PDB), but normal marine $\delta^{18} \mathrm{O}$ values $(-1.8 \%$ ). Carbon isotope analyses of Late Pliensbachian bulk carbonate (matrix) samples from the Fontaneilles section show clearly decreasing $\mathrm{C}$-isotope values across the A. margaritatus Zone, from $+1 \%$ o to $-3 \%$ o (V-PDB). Isotope analyses of coeval belemnite rostra do not document such a negative $\mathrm{C}$-isotope trend with values remaining stable around $+2 \%$ (V-PDB). Computer tomographic (CT) scanning of the tubular concretions show multiple canals that are lined or filled entirely with pyrite. Previously, the formation of these concretions with one, two, or more central tubes, has been ascribed to the activity of an enigmatic organism, possibly with annelid or arthropod affinities, known as Tisoa siphonalis. Our re-
\end{abstract}

Correspondence to:

B. van de Schootbrugge

(van.de.schootbrugge@em.uni-frankfurt.de) sults suggest tisoan structures are abiogenic. Based on our geochemical analyses and sedimentological observations we suggest that these concretions formed as a combination of the anaerobic oxidation of methane (AOM) and sulfate reduction within the sediment. Fluids rich in methane and/or hydrocarbons likely altered local bulk rock carbon isotope records, but did not affect the global carbon cycle. Interestingly, $\mathrm{Ti}^{-}$ soa siphonalis has been described from many locations in the Grands Causses Basin in southern France, and from northern France and Luxemburg, always occurring at the same stratigraphic level. Upper Pliensbachian authigenic carbonates thus possibly cover an area of many thousand square kilometers. Greatly reduced sedimentation rates are needed to explain the stabilization of the sulfate-methane transition zone in the sedimentary column in order for the tubular concretions to form. Late Pliensbachian cooling, reducing run-off, and/or the influx of colder water and more vigorous circulation could be responsible for a halt in sedimentation. At the same time (thermogenic) methane may have destabilized during a major phase of Late Pliensbachian sea level fall. As such Tisoa siphonalis is more than a geological curiosity, and its further study could prove pivotal in understanding Early Jurassic paleoenvironmental change.

Published by Copernicus Publications on behalf of the European Geosciences Union. 


\section{Introduction}

Here, we report on large columnar carbonate concretions discovered in outcrops in southern France. These occur in sediments of Early Jurassic age in the uppermost part of the Pliensbachian stage, just prior to black shales marking the Toarcian Oceanic Anoxic Event. These tubular concretions, known from southern France for at least 170 years, have been attributed to the activity of an enigmatic burrowing organism. As early as 1840, Marcel de Serres interpreted these concretions as fossils and named them Tisoa siphonalis (de Serres, 1840). De Serres thought them to be the fossilized skeletons of large squid-like animals, similar to belemnites, that lived in dense colonies on the sea floor (de Serres, 1842). As such, Tisoa siphonalis appeared as a mollusc in an early textbook on modern and fossil shells (Chenu, 1859). However, T. siphonalis has remained an enigma, mostly because all subsequent authors adhered to the biological origin for these presumed fossils. In 1869, the french paleontologist Eugene Dumortier devoted more than 20 pages to the detailed description of $T$. siphonalis in his life's work on the paleontology of the Lower Jurassic in France (Dumortier, 1869). During the late 19th century, the concretions must have occurred in large numbers in southern France, and among local farmers they were known as "Fromages de pere Adam" or "Adam's cheeses" (Dumortier, 1869). In Dumortier's view, T. siphonalis was made by a burrowing worm-like organism, similar to Arenicolites. In his type specimen from SaintFortunat (Department of Gard, France), Dumortier recognized two parallel canals that he assumed to form a U-shaped tube. It is important to point out that he did not see his type specimen in half - presumably so as not to destroy it - to make sure his interpretation was correct. However, Dumortier also noted that some of the tubular concretions had only a single "siphon", and that there were many with numerous tubes. In fact, De Serres (1842, p. 87) had already made the same observation, but he was convinced that these were "non pas de veritable siphons" and "faux siphons" (not true tubes and false tubes), because they strongly differed from the very regular tubes in the center of the concretions. De Serres (1842), and shortly thereafter Dumortier (1869), thus concluded that Tisoa had only 2 "true" siphons.

The observation that there are many siphons, or canals, in each concretion did not survive the test of time, because most of the later authors ignored this crucial feature. Instead, many authors struggled to explain the biogenic nature of the exceptionally large, and extremely narrow U-shaped tubes of Tisoa siphonalis (Bertling et al., 2006). In 1924, Bather provided a brief state-of-the-art in English, in which he supported the view that both central tubes are two limbs of an U-shaped worm-burrow. Probably unfamiliar with the fact that the Pliensbachian marls are rich in ammonites and belemnites, Bather ascertained that the animal lived in mudflats (Bather, 1924). Bather's ideas were disputed by Andree (1927) and by Maubeuge (1947). Maubeuge interpreted
Tisoa to be the remains of an alga, because in some of his specimens he observed a root-like structure at the base of the concretions. Based on abundant findings of Tisoa-like fossils in the Oligocene of Tunisia, Gottis (1954) contested the algal interpretation, but also struggled to imagine an organism that built parallel tubes $3 \mathrm{~m}$ long and only a few millimeters apart. The Jurassic T. siphonalis from southern France was briefly mentioned again by Stchepinsky (1937), and included by Lessertisseur (1955) as a possible worm-burrow in an early review on ichnofossils. Finally, T. siphonalis ended up, 135 years after its discovery, as a problematic ichnofossil in the Treatise on Invertebrate Fossils edited by Hänztschel (1975).

Here, we provide geological and geochemical evidence showing that Tisoa concretions are similar to well-known Recent and Cenozoic subsurface hydrocarbon conduits (Aiello et al., 2001; De Boever et al., 2006; Campbell et al., 2008) and that their formation was thus abiogenic. We also discuss the larger ramifications of our new interpretation in the context of Early Jurassic paleoclimatic and paleoceanographic changes taking place during that time.

\section{Geological setting}

We studied Lower Jurassic outcrops in the Lozère Department near the little town of Rivière-sûr-Tarn, approximately $15 \mathrm{~km}$ North of the city of Millau, and close to the town of Mende (Fig. 1). Both areas are located in the Grands Causses Basin that was mainly filled-in during the Lower to Upper Jurassic. In the region around Rivière-sûr-Tarn lowermost Jurassic (Hettangian) to Middle Jurassic (Bathonian) sediments are well exposed in a number of large canyons, of which the Tarn Canyon is the most famous. Jurassic sedimentation in southern France occurred in a number of interconnected shallow marine epicontinental basins that were bordered by the Central Massif to the North and were open to varying degrees towards the South, connecting with the open Tethys Ocean. These local basins were separated from eachother by paleo-highs and shallow carbonate platforms (Lemoine and de Graciansky, 1988; Dumont, 1988).

The relatively thick Lower Jurassic infill (up to $400 \mathrm{~m}$ ) of the Grands Causses Basin shows a typical deepening upward trend that reflects the long-term Early Jurassic first order sea level rise, and a return to shallower conditions during the Aalenian and Bajocian. Trümpy (1983) defined a number of Lower Jurassic formations that together form the Rivière-sûr-Tarn Group (Fig. 2). The Hettangian to lowermost Pliensbachian Bourg Formation is characterized by coarse grained fluviatile to marginal marine sandstones at its base, overlain by peritidal dolomicrites with subordinate clay beds that grade upwards into Sinemurian and Pliensbachian dark grey hemipelagic marl-limestone alternations. The Villeneuve Formation consists of a thick succession of organic matter rich Middle to Upper Pliensbachian marls with some 


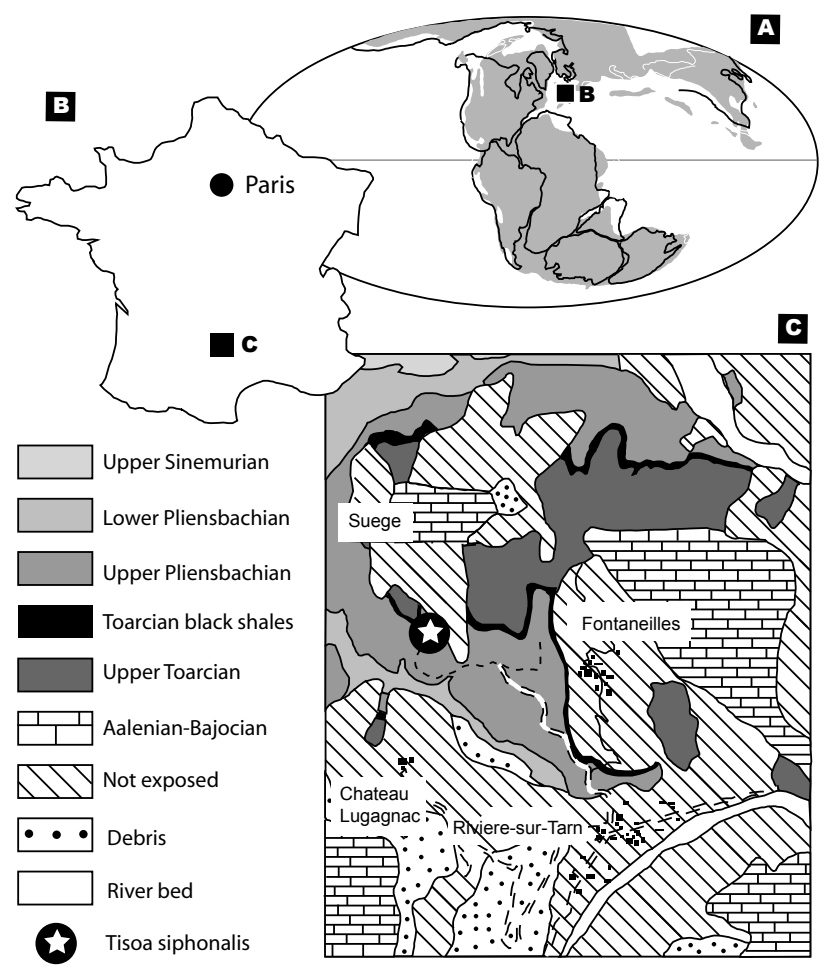

Fig. 1. Palaeogeographic, location, and geological sketch maps. (A) Paleogeographic reconstruction for the Early Jurassic modified after Scotese Paleomap Project. (B) Location map of France. (C) Simplified geological map (modified from sheet St-Beauzely) of the area around Rivière-sûr-Tarn with location of cold seep carbonates west of Fontaneilles. The outcrop of Fontaneilles can be located with the following coordinates: $44^{\circ} 12^{\prime} 15.33^{\prime \prime} \mathrm{N} / 3^{\circ} 6^{\prime} 25.34^{\prime} \mathrm{E}$. The outcrop at Truc-de-Balduc, which was primarily sampled for the Toarcian OAE can be located with the following coordinates: $44^{\circ} 28^{\prime} 25.87^{\prime \prime} \mathrm{N} / 3^{\circ} 30^{\prime} 36.00^{\prime} \mathrm{E}$.

intercalated carbonate beds. The lowermost Toarcian is composed of black shales typical of the Schistes Cartons Formation. These black shales weather distinctly from the underand overlying marly sediments and are easily recognizable in the field. On top of the Schistes Cartons Formation follows the Middle to Upper Toarcian Marnes de Fontaneilles Formation that is dominated by monotonous grey marls rich in ammonites, belemnites, bivalves and gastropods. Dark marls of the Fontaneilles Fm transition first into limestone-marl alternations and finally into sandy bioclastic carbonate platform sediments of Aalenian to Bajocian age (Cancellophycus facies).

We focused our attention on two sections. The Fontaneilles section, directly outside of Rivière-sûr-Tarn was studied in detail (Fig. 1c), because it is well exposed and represents a continuous succession from the Lower Pliensbachian up to the Aalenian. We also sampled a section at Truc-de-Balduc, because especially the lowermost Toarcian is difficult to access in Fontaneilles on a very steep hillside.

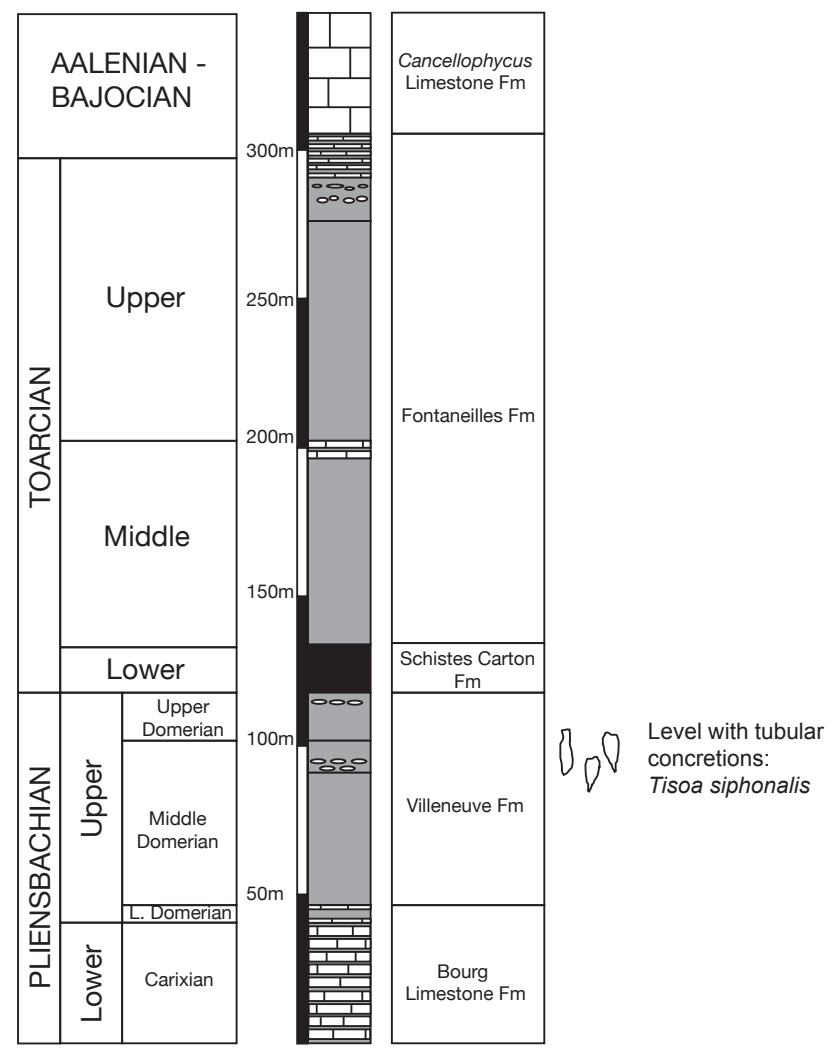

Fig. 2. Chrono- and lithostratigraphic framework for the Grands Causses Basin (southern France) for the entire Lower Jurassic (modified after Morard, 2004). The level with the tubular concretions is dated as Margaritatus Zone, Gibbosus Subzone.

Both sections represent a setting in the depocenter of the Grands Causses Basin, which was a half-graben separated from the open Tethys towards the South by the Languedoc sill, and bordered to the East by the Cevennes high and towards the West by the transition to the Quercy Basin. Previous work on the Pliensbachian-Toarcian transition in the area around Rivière-sûr-Tarn by (Morard et al., 2003; Morard, 2004) has brought to light a significant erosional gap between the latest Pliensbachian Spinatum Zone and the lowermost Toarcian Tenuicostatum Zone, corresponding to the Dactylioceras elisa and D. mirabile Subzones.

\section{Methods}

For our study we sampled concretions, bulk rock sediments, as well as belemnite rostra for stable isotope analyses. In total we analysed 213 bulk carbonate samples and 153 belemnites for $\mathrm{C}$ - and $\mathrm{O}$-isotopes from the Upper Pliensbachian to Aalenian. A detailed discussion of these stable isotope data will be provided by Harazim et al. (2010). Here, we focus on those parts of the bulk carbonate and belemnite isotope curves that cover the Upper Pliensbachian to lowermost 

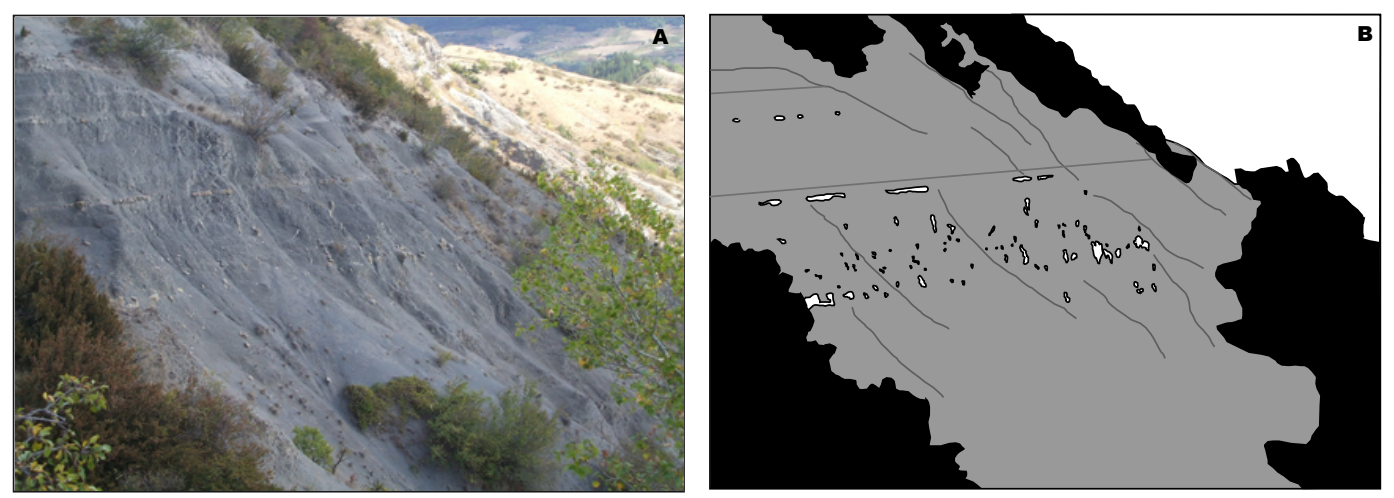

Fig. 3. (A) Image taken at Fontaneilles shows the upper part of the Pliensbachian Villeneuve Fm, approximately $10 \mathrm{~m}$ below the onset of the Schistes Cartons Fm. In the middle of the marl succession an interval of $10 \mathrm{~m}$ is dominated by large carbonate concretions, formerly known as the trace fossil Tisoa siphonalis. (B) The same image as in (A) in gray-tones.

Toarcian. We also obtained 46 stable isotope measurements from one of the carbonate concretions, both along its long and short axes. For carbon isotope analyses, a Gas Bench II (Thermoquest) was connected to the continuous flow inlet system of the MAT 253 mass spectrometer. A detailed description of the analytical setup and the analytical method itself has been given by Spoetl and Vennemann (2003). Each sample was analyzed in duplicates, ranging in size from 50$100 \mu \mathrm{g}$. An internal standard, calibrated against NBS18 and NBS19, was run along with the samples (Fiebig et al., 2005). Internal precision was better than \pm 0.05 for $\delta^{13} \mathrm{C}$ and \pm 0.08 for $\delta^{18} \mathrm{O}$.

In order to make internal structures of the large carbonate concretions visible we employed computer tomography. For CT-imaging the carbonate samples were scanned with a Phillips CT Brilliance 6-Line Scanner in the Institute of Neuroradiology at the university hospital of the Goethe University Frankfurt. The tube voltage was set to $120 \mathrm{kV}$ and the pixel spacing to $0.35 \mathrm{~mm}$ at an image matrix size of $512 \times 512$ pixel for all CT studies. Spacing between slices varied from $0.6 \mathrm{~mm}$ for smaller samples to $1.0 \mathrm{~mm}$ for larger ones (obtaining approx. 300 slices for each sample). Further processing and visualization of the volume data was performed with the software application Smoooth. Here, a threshold method was suitable for object segmentation inside of the volume data due to the high contrast between pyrite and surrounding carbonate matrix.

\section{Results}

A striking feature of the Upper Pliensbachian in the Fontaneilles section is the presence of large columnar carbonate concretions, which occur in a $15 \mathrm{~m}$ thick interval in the upper part of the Villeneuve Fm, approximately $10 \mathrm{~m}$ below the onset of the Schistes cartons Fm. Based on ammonites sampled during fieldwork, this interval can be as- signed to the Gibbosus Subzone, corresponding to the uppermost part of the Margaritatus Zone (Figs. 2, 3, and 4; and see Harazim et al., 2010). A detailed study of the ammonite fauna by Morard (2004) in the nearby section of Tournemire (region of Aveyron, southern France) confirms our findings and shows the concretionary interval to occur directly below the first appearance of the ammonite Pleuroceras transiens marking the P. transiens Subzone (lower part of the Spinatum Zone). The carbonate concretions are tubular or columnar bodies with a subspherical or ovoidal shape. They are mostly oriented with their long-axis normal to the bedding plane and vary in length from $30 \mathrm{~cm}$ to up to $1 \mathrm{~m}$ (Fig. 4a). Some of the concretions also show lateral branching, giving the impression of a network.

In outcrop, the base of one of the investigated concretions was surrounded by large amounts of highly weathered pyrite (Fig. 4b). Although the surrounding matrix consists mainly of marly sediments, much like lower down in the Pliensbachian or higher up in the Toarcian, these marls differ from the overlying and underlying interval in that they generally appear to be more indurated. Induration could be the reason why this interval is perceived to be scarce in macrofossils, as noted by de Brun and Brousse (1936). Cross-sectioned parallel to its long-axis (Fig. 4c), one of the concretions shows a clear, albeit irregular, central canal that is filled with pyrite and presumably calcite. The canal is thinning towards the lower end. Septarian cracks filled with sparry calcite are extending from this central canal (Fig. 4c). In another specimen, seen from above, the septarian cracks radiate from the centre and cross-cut the central canal indicating a later formation (Fig. 5a). In a specimen, cross-sectioned perpendicular to its long axis, there is not one single central canal visible, but there are at least two larger canals in the center, and there are numerous smaller ones irregularly distributed throughout the concretion, which are also filled with pyrite (Fig. 6). In cross-section it is possible to observe at least two generations of septarian cracks, with the most prominent 

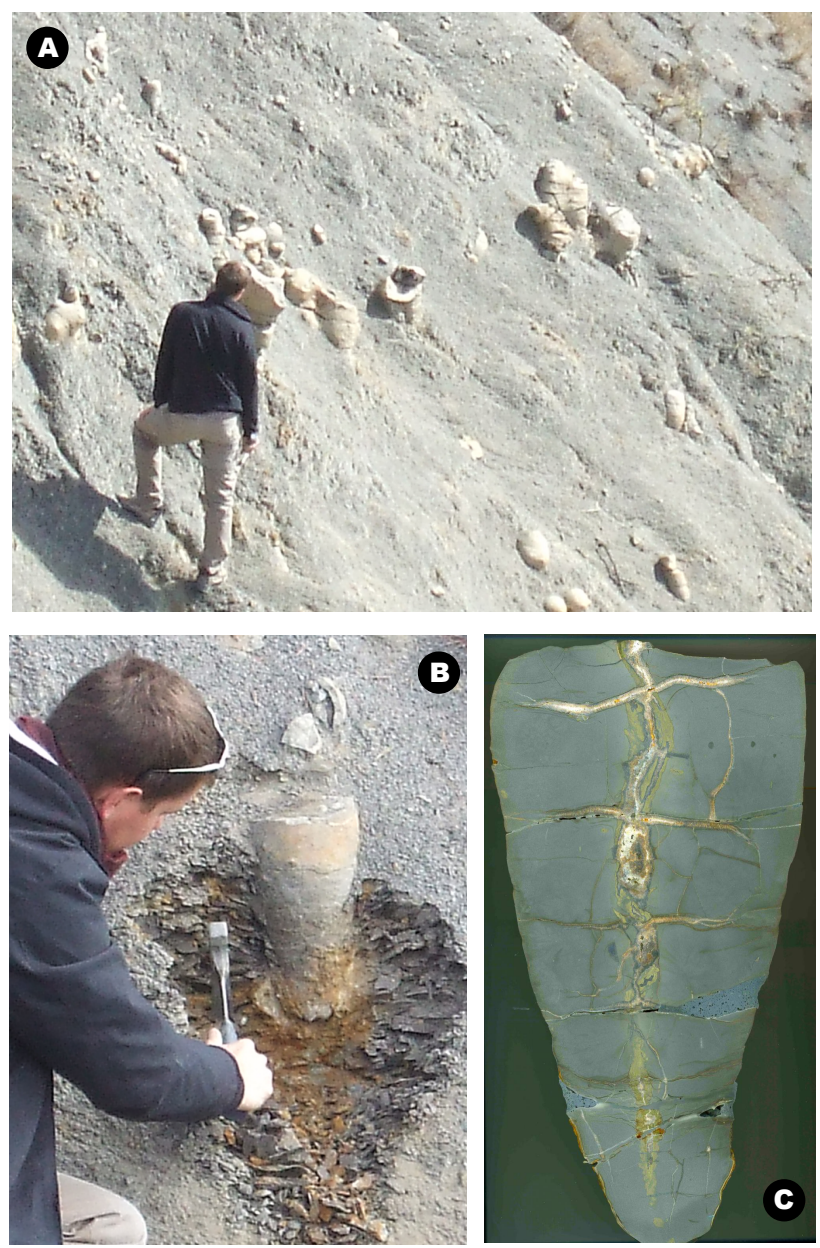

Fig. 4. (A) Detailed view of seep interval with authigenic carbonates. The person for scale is $1.85 \mathrm{~m}$ tall. (B) Close-up of the columnar carbonate concretion that was sampled and analyzed in this study. (C) A cross-section of the columnar carbonate concretion clearly showing the central canal and septarian cracks filled with late diagenetic minerals.

cross-cutting an earlier phase of septarian cracking. The lining of the second generation septarian infilling show two distinct types of calcite cement clearly distinguishable in Fig. 6. The first phase is characterized by brown-coloured blocky calcite, and the second phase consists of white-coloured calcite spar. We also observed conspicuous millimeter thick pyrite bands along one of the septarian cracks.

Carbon and oxygen isotope analyses of one of the carbonate concretions show a clear trend along a margin to center transect (Fig. 6). Within the concretion, $\delta^{13} \mathrm{C}_{\text {carb }}$ values decrease from the rim $(-18.8 \%$ V-PDB $)$ towards the center $(-25.7 \%$ V-PDB). Concomitantly, oxygen isotopes show "normal marine" values around $-2 \%$ (V-PDB) along the same transect (Fig. 6). Carbon and oxygen isotopes vary little from the top to the bottom, parallel to the central canal, with values averaging around $-25 \%$ o for carbon and $-2 \%$ o
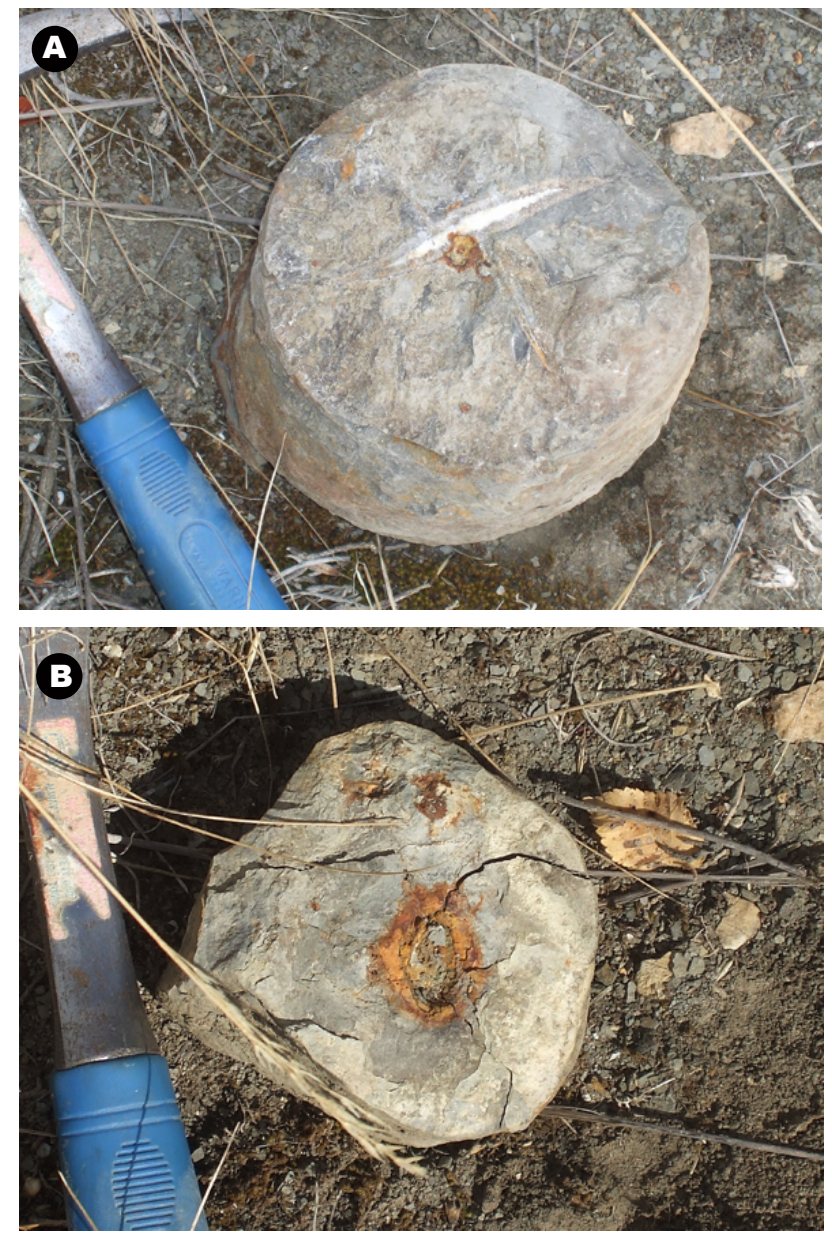

Fig. 5. Detailed images of 2 concretions ( $\mathbf{A}$ and $\mathbf{B}$ ), with clearly visible central canals that are filled with or lined by weathered pyrite.

for oxygen. Such $\delta^{18} \mathrm{O}$ values indicate carbonate sedimentation close to the sediment-water interface without major diagenetic overprint. Oxygen isotope values of the concretionary micrite are only slightly more negative than $\delta^{18} \mathrm{O}$ values obtained from contemporaneous belemnites. C-isotope values sharply increase again in the center of the concretion (around $0 \%$ ) together with very negative $\delta^{18} \mathrm{O}$ values (around -9\%; Fig. 6). This inverse correlation between carbon and oxygen isotopes for the central part, suggests that the calcite that is in the septarian cracks originated through a different process than the micrite of the concretions themselves. Isotope values of the septarian calcite are distinctly different from carbon and oxygen isotope values from the mass of the concretionary carbonate, which is clearly seen in the cross-plot of Fig. 7.

Bulk carbonate and belemnite stable isotope data presented in Fig. 8 were obtained from two overlapping records from the Fontaneilles and Truc-de-Balduc sections. Overall, data in this composite record present a coherent longterm isotope trend for both carbon and oxygen. The only 


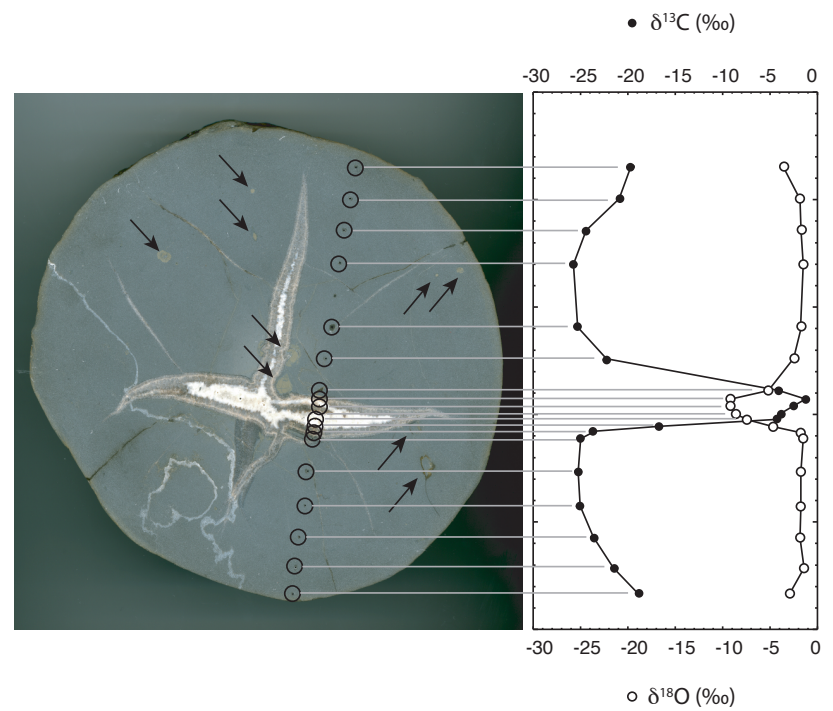

Fig. 6. Carbon and oxygen isotope values from a Tisoa concretion (same concretion as shown in Fig. 1c). Carbon isotope values decrease from the rim to the center and reach a minimum value of $-25.7 \%$ (V-PDB). Oxygen isotopes display typical marine values.

exception is the bulk O-isotope record, which is offset in Fontaneilles compared to Truc-de-Balduc. In general bulk carbonate $\delta^{18} \mathrm{O}$ values are relatively low, around $-4 \%$ o to $-6 \%$ o for the Pliensbachian, which suggests some overprint from burial diagenesis. Bulk carbonate $\mathrm{C}$-isotope values show a long-term decreasing trend across the Upper Pliensbachian in the Fontaneilles section (Fig. 8). Carbon isotope values decrease from approximately $+1 \%$ o (V-PDB) in the Davoei Zone to $-3 \%$ (V-PDB) in the lowermost Spinatum Zone. Within the Pleuroceras solare Subzone C-isotope values abruptly increase again in both the Fontaneilles and Truc-de-Balduc sections to values around $+1 \%$ o. A second positive shift is observed in the Toarcian Schistes Cartons $\mathrm{Fm}$. A large negative excursion in bulk carbonate $\delta^{13} \mathrm{C}$, that has been controversially discussed, is based on one single data point $(-5.94 \%$ ) in the Truc-de-Balduc section obtained from the first massive carbonate bed within the black shale succession. In contrast to bulk carbonate $\mathrm{C}$-isotopes, belemnite $\delta^{13} \mathrm{C}$ does not show the gradual decrease in values across the Upper Pliensbachian. Belemnite $\mathrm{C}$-isotope values remain stable around values of $+1 \%$, and increase during the Toarcian to reach $+4 \%$.

Considering that belemnites are generally thought to carry pristine $\mathrm{C}$-isotope values, especially on longer timescales, the difference between the bulk carbonate and belemnite $\mathrm{C}$ isotope records suggest that bulk carbonate $\mathrm{C}$-isotopes from the Upper Pliensbachian may have been overprinted by secondary processes. Two observations argue against burial diagenesis to explain these anomalous bulk carbonate $\mathrm{C}$-isotope values: (1) burial diagenesis would have overprinted all Cisotope values and not just those obtained from the Margar-

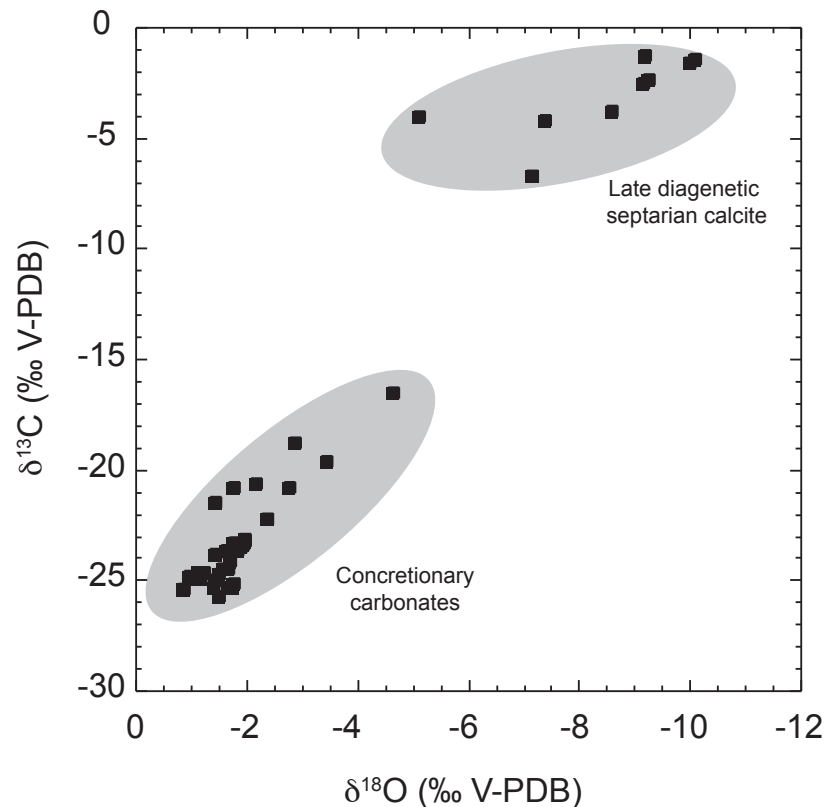

Fig. 7. Cross-plot of carbon and oxygen isotope values as shown in Fig. 6. Values obtained from septarian calcite are cleary distinguishable from values obtained from the concretion mass, suggesting a different, late diagenetic process. The more negative oxygen isotope values could be the result of interaction with meteoric water.

itatus and Spinatum Zones, and (2) burial diagenesis would have also altered belemnite $\mathrm{C}$-isotope values. Below we will discuss a scenario that links the anomalous $\mathrm{C}$-isotope values in the Upper Pliensbachian to the occurrence of Tisoa siphonalis.

\section{Discussion}

\subsection{Hydrocarbon seep origin for Tisoa siphonalis?}

No skeletal remains have ever been found in association with the tubes. This was the main reason why Dumortier (1869) interpreted T. siphonalis as the burrow of a soft-bodied organism, instead of a bivalve or arthropod. The size and shape of the burrows is astonishing. In today's world there are no organisms, such as polychaetes, capable of building U-shaped tubes that would resemble T. siphonalis. Furthermore, it is hard to imagine how a small-sized organism would be able to keep water flowing in such a large burrow. The exclusive association of the tubes with concretions is also puzzling. Bather (1924) suggested that the animal secreted large amounts of mucus that would help stiffen the burrow-walls and would, on death of the animal, become fossilized as a tubular concretion, rich in pyrite. We now know that a number of physico-chemical conditions need to be met, in order for a concretion to be formed (see also discussion below). Tisoa has thusfar only been recognized in 


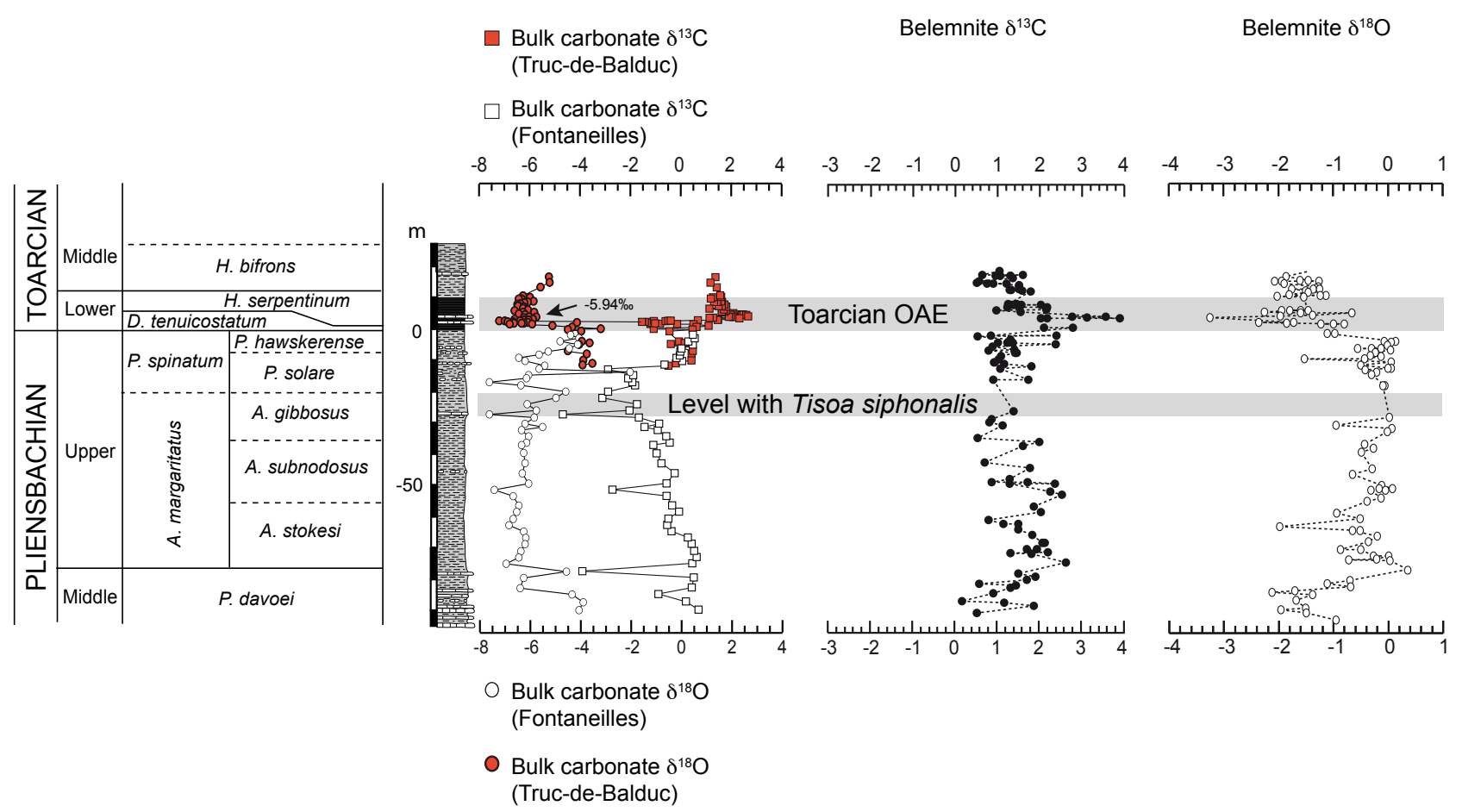

Fig. 8. Carbon and oxygen stable isotope results from the Fontaneilles section for bulk carbonates and belemnites. Bulk carbonate oxygen isotope values are likely compromised by diagenetic processes resulting in relatively low values around -6\%o (V-PDB). Bulk carbonate carbon isotope values clearly decrease during the Margatitatus Zone and reach a minimum in the Spinatum Zone, after which values increase again to typical marine values of $+1 \%$.

Upper Pliensbachian marls in Europe, in Oligocene flysch in Tunisia, and in the Oligocene of Washington state, USA (Frey and Cowles, 1972), which raises the question why it disappeared from the fossil record for more than 150 million years between the Early Jurassic and Oligocene.

The study by Frey and Cowles (1972) on Tisoa from the Lincoln Creek Fm exposed at Megler (Washington, USA) is particularly illustrative for the many problems associated with a biogenic interpretation. Although Frey and Cowles (1972) compare them with Lower Jurassic Tisoa from France, most of their concretions are much smaller in size (maximum of $15 \mathrm{~cm}$ ). They are similar in the sense that the tubes are very close to each other and are lined with pyrite. Only in one specimen were these authors able to show something that resembles a U-shaped tube. However, a salient detail in their work is the fact that at other localities near Megler, the single-tube variety is actually much more common than the twin-tube version. Moreover, Frey and Cowles (1972) reported spiraled forms and branching types, leading them to suggest that multiple genera of Tisoa-like organisms (sic) were involved.

The tubular carbonate concretions discussed here show comparable characteristics to tubular concretions in recent and ancient hydrocarbon-bearing marine settings where they indicate channelized fluid flow. Such ancient examples
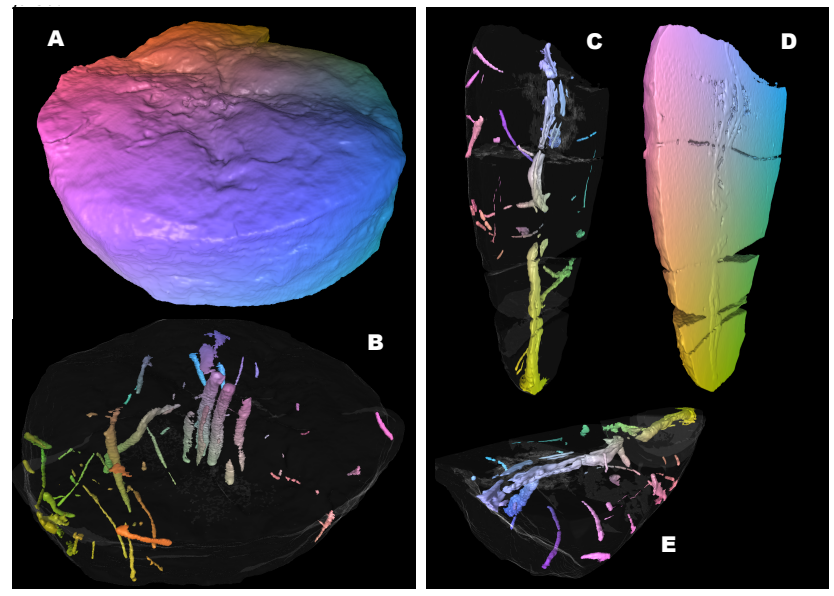

Fig. 9. CT-scans of Tisoa siphonalis

themselves show many characteristics of authigenic carbonate concretions and crusts associated with cold seeps in the present-day ocean (Pierre and Fouquet, 2007). Large columnar carbonate concretions have been described from the Miocene in California, Italy and New Zealand (Aiello et al., 2001; Aiello, 2005; Campbell et al., 2008; Cavagna et al., 1999). Especially the examples from New Zealand 


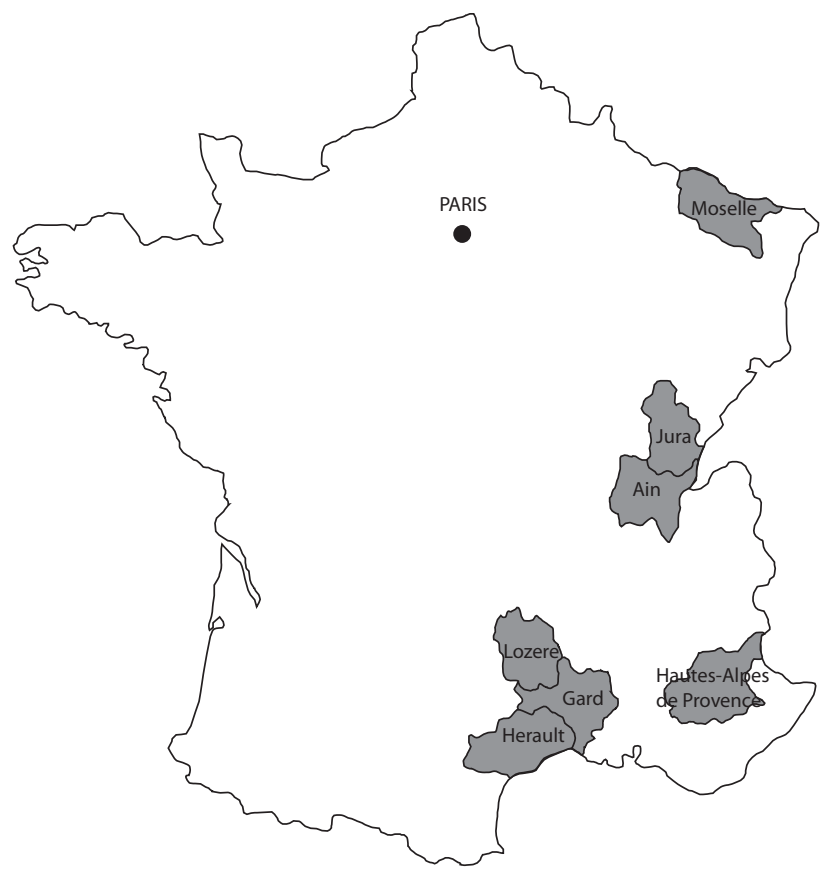

Fig. 10. Map of France showing departments that have Tisoa siphonalis present in Upper Pliensbachian outcrops. These outcrops are listed in the supplementary material.

are strikingly similar to the Pliensbachian tubular concretions described here (Campbell et al., 2008). Tubular concretions, some 5-10 $\mathrm{m}$ in length, from the North Island of New Zealand typically have a central conduit, but some show multiple conduits (Nyman et al., 2009). Radiating from these conduits are septarian cracks filled with late diagenetic calcite. Nyman et al. (2009) described many different morphologies ranging from large single-tubed pipes to concretionary, brecciated blocks with multiple canals. Originally, these so-called paramoudras were also interpreted as trace fossils, but sedimentological and organic geochemical data clearly indicate that they are subsurface conduits formed during hydrocarbon seepage (Schellenberg, 2002; Pearson et al., 2005b).

The strongest evidence for the abiogenic nature of Tisoa siphonalis is its characteristic C- and O-isotope pattern of negative $\mathrm{C}$-isotope values and "normal" $\mathrm{O}$-isotope values. The carbon isotope values derived from the investigated $\mathrm{Ti}$ soa are offset by more than $20 \%$ ofrom the surrounding bulk carbonate, which have themselves atypical values of $-3 \%$ o and by nearly $30 \%$ from co-occurring belemnites $(+2 \%)$. Similar negative $\mathrm{C}$-isotope values $(-28 \%$ ) have been obtained from Oxfordian carbonate nodules from an outcrop at Beauvoisin, France (Louis-Schmid et al., 2007). These Oxfordian nodules are associated with dense accumulations of fossilized cold seep lucinid bivalves (Peckmann et al., 1999a; Louis-Schmid et al., 2007). The Oxfordian nodules not only show similar absolute $\mathrm{C}$-isotope values but also similar trends as observed in our specimens: decreasing $\delta^{13} \mathrm{C}$ values towards the center (from $-26.7 \%$ o to $-30.4 \%$ ) and normal $\delta^{18} \mathrm{O}$ values (around $0 \%$; Louis-Schmid et al., 2007). The stable isotope values obtained from Tisoa are also comparable to those obtained by Peckmann et al. (1999a) from Eocene seep carbonate concretions in Italy. Eocene carbonate-cemented chimneys from Bulgaria (De Boever et al., 2006) also show negative C-isotope values (bulk of the data at $-20 \%$ o some values up to $-43 \%$ ), and their carbon and oxygen isotopes are inversely correlated. Sinemurian mud volcanoes in the UK (Allison et al., 2008; Price et al., 2008), as well as Pliensbachian-Toarcian seep bioherms from Argentina (Gomez-Perez, 2003) have C-isotope compositions that are within the range reported here.

Septarian concretions can form in the sediment at any time, right after deposition of the host sediment, or millions of years later (Arndt et al., 2009). Concretions that form during local degradation of organic matter are often round, occur preferentially parallel to the bedding, and lack indications of fluid flow through the sediment, such as conduits. Stable isotope records of such concretions are also clearly different. Carbonate carbon isotope values are generally more positive, ranging from $-15 \%$ to values typical for marine carbonates. Kimmeridgian septaria from Staffin Bay, Scotland, have $\delta^{13} \mathrm{C}$ values ranging from $-17 \%$ o to $0 \%$ (Hendry et al., 2006; Pearson et al., 2005a). These C-isotope values are thought to represent a mixture of $\mathrm{CO}_{2}$ arising from bacterial sulfate reduction of in situ organic matter and surrounding carbonate, leading to moderately depleted $\delta^{13} \mathrm{C}$ values. Devonian concretions from the Rhinestreet black shale have $\delta^{13} \mathrm{C}$ values ranging from $-14 \%$ to $+1.5 \%$, and $\delta^{18} \mathrm{O}$ values ranging from $-6 \%$ to $-4 \%$ (Lash and Blood, 2004). The interpretation of $\delta^{\mathrm{x} 8} \mathrm{O}$ in such diagenetic septarian concretions is more problematic as they tend to be often extremely negative, sometimes as negative as $-14 \%$ oSuch findings contrast with our results for Tisoa siphonalis.

Based on the characteristic pair of low $\delta^{13} \mathrm{C}$ and high $\delta^{18} \mathrm{O}$ values, and decreasing $\delta^{13} \mathrm{C}$ values from rim to center, we suggest that the tubular carbonate concretions formed at the sulfate-methane transition zone due to the coupled process of the anaerobic oxidation of methane and sulfate reduction. This process led to a rise in carbonate alkalinity triggering the precipitation of micrite with negative $\mathrm{C}$-isotope values, but normal $\mathrm{O}$-isotope values. The production of $\mathrm{H}_{2} \mathrm{~S}$ led to pyrite precipitation within the conduits. The very negative carbon isotope values in the Tisoa concretions suggest mixing of fluids with a depleted carbon isotope composition, possibly methane, with background carbonate sediments. Background $\mathrm{C}$-isotope values most likely had values that were similar to belemnite $\mathrm{C}$-isotope values of around $+1 \%$. The decreasing upwards trend and the negative values recorded by the bulk carbonate indicate seepage of fluids altering the original C-isotope composition. The carbon isotope composition of the source is difficult to determine, because the end-product, i.e. the carbon isotope signature recorded in the 
Tisoa concretions, will depend on fluid rate intensity and duration.

There is possibly one way to reconcile the abiogenic and biogenic interpretations of Tisoa. Today, cold seep sites are sometimes dominated by vestimentiferan tubeworms, such as Lamellibrachia, that can grow a posterior extension, known as a "root", up to several meters into the sediment (Freytag et al., 2001). They do so in order to acquire sulfide that is needed by their chemosymbiotic bacteria. Root-like structures at the lower end of the Tisoa concretions have been described by Friren (1887) and Maubeuge (1947) for Jurassic specimens, and by Gottis (1954) for the Oligocene specimens. It is difficult to assess these observations, because none of above mentioned authors provided drawings or photographs of these root-like structures. We did not observe similar structures in our investigated specimens. Nevertheless, the roots in modern tubeworm species are extremely chaotic masses ("root-balls"; Haas et al., 2009), and would not produce the kind of tubes present in our specimens.

The computer tomographic-scans are particularly helpful in order to further negate the biological origin of Tisoa siphonalis. Because the canals are filled with pyrite, the density contrast results in excellent imaging of the internal structure of the concretions, with surprising results (Fig. 9). The CT-scans show that the most pronounced canals are in the center of the concretions. However, the concretions do contain many regular and irregular smaller canals. The random distribution of these canals makes a biogenic origin even more unlikely. Some of these smaller canals appear to be branching-off from the central canals. A puzzling feature of the tubes is that they often occur in groups of two closely spaced canals (Figs. 6 and 9). At the moment we have no satisfactory phyiscal explanation for this phenomenon. Background sedimentation, in this case fine-grained marls, could set the boundary conditions for the formation of the tubes. Tubular carbonate concretions with a great variety of conduits, including twin-tubed ones, have been dredged from the Gulf of Cadiz (Diaz-del-Rio et al., 2003), an area known for its abundance in mud volcanoes and other hydrocarbon seep related structures. Some seep-related dolomitic concretions from the Tortonian in Morocco (Pierre and Rouchy, 2004) and Eocene of Bulgaria (De Boever et al., 2006) also show multiple conduits.

\subsection{Distribution of Upper Pliensbachian authigenic carbonates}

In the late 19th century, it would have been impossible for De Serres and Dumortier to have made a correct interpretation of Tisoa siphonalis, because methane seepage and associated chemosynthetic communities on the sea floor were only first discovered during the eighties of the last century, more than one hundred years later. The true value of the work by de Serres and Dumortier is that they stress the great number of concretions that always appear at the same stratigraphic level, across an enormous surface area. Whereas De Serres described them mostly from the Lozère and Gard departments, Dumortier found them all over the Rhone Basin in the departments Gard, L'Herault, Bouches-du-Rhone, Ardêche, Ain and Jura (Fig. 10). Many of the sites mentioned in Dumortier (1869) are difficult to trace, because geographic names of villages and towns have changed. However, some of the earlier observations have in part been confirmed by later authors (de Brun and Brousse, 1936; Mattei, 1986; Cassel, 1997; Morard, 2004). During fieldwork in October 2009 (work in progress) we were able to confirm the presence of T. siphonalis in outcrops close to Durquies, and near the castle of Fressac, which is one of the locations listed in $\mathrm{Du}-$ mortier (1869) on the other side of Massif Central, approximately 100 km East of Rivière-sûr-Tarn.

A compilation of all locations based on a literature survey (see also supplementary material) indicates that T. siphonalis is widespread in Southern France and has been observed there in 21 Upper Pliensbachian outcrops. In fact, T. siphonalis is so characteristic and easy to recognize in the field that its serves as a marker for the upper part of the Margaritatus Zone and its presence is frequently mentioned in guide books that accompany several of the geological maps of southern France (e.g. sheet St-Beauzely, Mennessier and Collomb (1986); sheet Millau, Mennessier et al., 1984). The distribution of tubular carbonate concretions in southern France appears to be controlled by the occurrence of basin sediments in the form of marls of Late Pliensbachian age. On the basin margins, Upper Pliensbachian bioclastic carbonate sedimentation does not show evidence for authigenic carbonate concretions (Morard, 2004).

The distribution of Tisoa siphonalis is not limited, however, to southern France. It has also been described from the Upper Pliensbachian further North, for example from the Lorraine in northern France (Bleicher, 1887), from the region around Metz close to Thionville (Friren, 1876, 1887), and from Luxemburg, close to Bettembourg (Maubeuge, 1947). Tisoa siphonalis in those areas is very similar to specimens from southern France with one major difference: the size of the concretions never exceeds several tens of centimeters. A re-investigation of these occurrences is clearly needed. Nevertheless, we can conclude that the formation of authigenic carbonate concretions was a very widespread phenomenon during the Late Pliensbachian, which begs for an explanation within the context of Early Jurassic paleoenvironmental changes.

\subsection{Scenarios for widespread Late Pliensbachian authigenic carbonate deposition}

The formation of large carbonate concretions due to channelized fluid flow with fluids rich in hydrocarbons is controlled by the interplay of physical and chemical processes. A major sedimentary break, which could be an omission surface or an erosional hiatus, is one of several important prerequisites to 
explain the formation of large concretions in the sedimentary column. Large authigenic carbonate concretions, linked to the mobilization of fluids along the Californian active margin, are concentrated beneath a major unconformity that separates the Miocene Santa Cruz Mudstone Fm from the overlying Purisima Fm (Aiello et al., 2001). Dramaticaly reduced sedimentation rates, non-deposition, or submarine erosion leads to stabilization of the sulfate-methane transition zone (SMTZ) within the sediment, allowing for constant downward diffusion of sulfate from sea water. The anaerobic oxidation of methane, providing the alkalinity needed to trigger authigenic carbonate precipitation, takes place exactly at the level where sulfate and methane co-occur (Raiswell and Fischer, 2004; Lash and Blood, 2004). In most sedimentary environments today the SMTZ is situated several meters to tens of meters below the sediment-water interface, but it can occur much deeper, up to $100 \mathrm{~m}$ below the surface (Gay et al., 2010). Tectonic activity is a dominant control on fluid mobilization in a number of paleo-seeps, allowing for the advection of fluids rich in hydrocarbons and/or methane. For example, synsedimentary tectonic activity, related to rifting in the Tethys, is thought to have controlled formation of the Oxfordian seeps at Beauvoisin (Louis-Schmid et al., 2007; Peckmann et al., 1999a). Similarly, mobilization of fluids in the Santa Cruz Fm has been linked to uplift and focused fluid flow along fractures, in an area bounded by large faults (Aiello et al., 2001). Large carbonate pipes of Eocene age in Bulgaria show a fault-related clustering (De Boever et al., 2006). Hence, to understand the formation of Tisoa siphonalis tubular concretions, two questions need to be addressed: (i) Is there evidence for a depositional break stratigraphically above the level with Tisoa siphonalis? (ii) Is there evidence for large scale tectonic activity during the Late Pliensbachian?

A major Late Pliensbachian (base Spinatum Zone, Solare Subzone) unconformity has been recognized in the neighbouring Ardêche area by Razin et al. (1996). In basin margin sections this sedimentary break is characterized by strongly brecciated carbonates. On the other side of the Rhône, in the Southern Provence Subbasin, the uppermost Pliensbachian (Spinatum Zone) is truncated and covered by a ferruginous hardground (Leonide et al., 2007). Further South, in the Causse-du-Larzac, a regionally significant starvation event is present in the form of a highly condensed hardground, that contains Sinemurian and Pliensbachian ammonites, and possibly marks a hiatus of 9 Ma (Merzeraud et al., 1999). More relevantly, a depositional hiatus that spans the uppermost Pliensbachian (Elisa Subzone) and lowermost Toarcian (Mirabile Subzone) in the Grands Causses Basin, has been demonstrated by Guex et al. (2001), Morard et al. (2003), and Morard (2004). The duration of this erosional gap is estimated to be on the order of 200-300 kyr (Guex et al., 2001). In addition, uppermost Pliensbachian marls (Spinatum Zone) in the Grands Causses Basin are enriched in phosphate, often in the form of nodules, which is a further indication of con- densation and reworking during this time (Morard, 2004). Although the contact between the Toarcian black shales and the underlying Pliensbachian marls is sharp, there is no evidence for emergence and erosion in the Fontaneilles section, hence, submarine erosion through currents, and condensation more likely explain the missing ammonite zones in basin settings.

Early Jurassic accomodation space and sediment accumulation in southern France were strongly influenced by both tectonics and sea level fluctuations (Leonide et al., 2007). Rapid subsidence due to extensional tectonics during the Pliensbachian Margaritatus Zone, together with generally high sea level stand, led to infilling of basins with thick successions of organic-rich marls (Leonide et al., 2007). In the Grands Causses Basin, the bulk of the Upper Pliensbachian is concentrated in the Margaritatus Zone. However, sedimentation rates decreased significantly towards the end of the Pliensbachian. For the Ardêche margin and the Causse-du-Larzac the regional expression of starvation, erosion, and hardground formation has been linked to largescale block faulting that started during the Sinemurian and continued during the Pliensbachian (Merzeraud et al., 1999; Razin et al., 1996). A large-scale hydrothermal event, leading to the formation of economically valuable $\mathrm{Pb}-\mathrm{Zn}$ deposits around the margins of the Cevennes region, has been dated at $185 \mathrm{Ma} \pm 15 \mathrm{Ma}$ based on K-Ar dating of illite clay minerals (Clauer et al., 1996). Since similar recrystallisation ages were obtained from North Africa, Clauer et al. (1996) suggested that further opening of the Central Atlantic during the Early Jurassic led to pulsed heating of the European continent. However, more accurate dating of these mineralizations using paleomagnetic analyses, indicate that hydrothermal fluids were mobilized much later, during a major phase of Early Eocene compressional deformation due to the Pyrenean orogeny (Henry et al., 2001; Rouvier et al., 2001). At the moment we can not exclude a tectonic control on fluid mobilization and the formation of Late Pliensbachian concretions based on only a handful of outcrops, however we deem this mechanism unlikely, because it would require the simultaneous activation of faults and the mobilization of fluids all across France and Luxemburg. Furthermore, the Early Jurassic in southern France shows multiple unconformities and extensional tectonism was active throughout the interval starting at the base of the Hettangian (Leonide et al., 2007). None of the other unconformities appear to be associated with fluid mobilization and hydrocarbon seepage.

A mechanism that could explain the occurrence of both Late Pliensbachian sedimentary breaks and the deposition of authigenic carbonates is related to major sea level fluctuations. Eustatic sea level fall has been implicated in the destabilization of gas hydrates and long-term modulation of fluid flow on Hydrate Ridge (Teichert et al., 2003). Sea level lowering could drive a destabilization of gas hydrates in shallower settings (Teichert et al., 2003). A compilation of cold seep carbonate occurrences through the past 150 million 
years by Kiel (2009) shows a strong correlation with sea level and deep water temperatures. High sea level during the Late Cretaceous correlates with a general absence of cold seep carbonates in the fossil record, whereas decreasing deep water temperatures and lower sea level for the past $40 \mathrm{Ma}$ correlate with increased abundance of fossil seep occurrences. Kiel (2009) suggests that during times with colder bottom waters more gas hydrates may have formed on shelfs, which may have then destabilized during rapid eustatic sea level swings.

Guex et al. (2001) have proposed that major sea level fall during the latest Pliensbachian was triggered by the buildup of ice-caps. Evidence for a Pliensbachian "cold snap" based on records of glendonites and dropstones was compiled by Price (1999). Oxygen isotope records derived from belemnite calcite (Bailey et al., 2003; Rosales et al., 2004; van de Schootbrugge et al., 2005a, b) and fish tooth apatite (Dera et al., 2009a) indicate that seawater temperatures declined significantly during the Margaritatus and Spinatum Zones. In the Fontaneilles section, a belemnite oxygen isotope record shows persistent cooling into the Spinatum Zone, i.e. during deposition of Tisoa siphonalis concretions (Fig. 8). Whether sea water temperature changes reflect changes in paleoceanography, with the arrival of cold Boreal water, or true climatic cooling as suggested by Guex et al. (2001) remains unclear. Fact is that low amounts of kaolinite in this time interval, as compared to the Lower Pliensbachian and Toarcian, indicate an increase in aridity across NW Europe and concomittant decrease in run-off during the Late Pliensbachian (Dera et al., 2009b).

To conclude we envision the following scenario: Major sea level lowering during the Pliensbachian across NW Europe, which could be either eustatic or due to large-scale geodynamic movements, led to low sedimentation rates, condensation (enrichments in phosphorus), and possibly submarine erosion. Generally colder water conditions may have made European epicontinental seaways prone to gas hydrate storage, whereas further sea level fall may have triggered their subsequent destabilization. Stability of the SMTZ for prolonged periods of time provided ideal conditions for anaerobic oxidation of methane and sulphate reduction, triggering the deposition of authigenic carbonate concretions with fluid flow conduits, formerly known as Tisoa siphonalis.

\subsection{Implications for the Toarcian Ocean Anoxic Event}

The Toarcian oceanic anoxic event (T-OAE; Jenkyns and Clayton, 1986; Jenkyns, 1988; Jenkyns and Clayton, 1997; Hesselbo et al., 2000) has drawn considerable attention over recent years, because the deposition of black shales has been proposed to be related to the massive release of methane from gas-hydrates, and/or from the intrusion of the Karoo-Ferrar Large Igneous Province into Carboniferous coal beds, triggering rapid global warming (Kemp et al., 2005; McElwain et al., 2005; Svensen et al., 2007; Hermoso et al., 2009).
The Methane Hypothesis was first proposed after recognizing large, simultaneous negative C-isotope excursions (CIE) of up to $-7 \%$ o (V-PDB) in the Exaratum Subzone of the Falciferum ammonite Zone in marine organic and carbonate carbon substrates, and in fossil wood (Hesselbo et al., 2000, 2007). The simultaneous negative offset in marine and terrestrial carbon reservoirs has been taken as evidence for the abrupt release of large amounts of isotopically depleted methane $\left({ }^{13} \mathrm{C}\right.$ of $-60 \%$ V-PDB $)$ from the melting of sea floor clathrates (frozen hydrated methane-gas) that would impart, on oxidation to $\mathrm{CO}_{2}$, a light $\mathrm{C}$-isotope value to all carbon reservoirs (Hesselbo et al., 2007).

Alternative views on the nature of the Toarcian negative CIE have been expressed by (van de Schootbrugge et al., 2005b; Wignall et al., 2005; Wignall et al., 2006; McArthur et al., 2007; Newton and Bottrell, 2007; Wignall and Bond, 2008; McArthur et al., 2008). One unresolved issue is the apparent diachroneity of black shale deposition. In Italy and Spain, black shale deposition seems to have started earlier than in Germany and England. Also the duration of the negative $\mathrm{C}$-isotope excursion remains an issue. Hesselbo et al. (2000) assumed a brief duration of $\sim 70000$ years, much in line with similar estimates for the global negative CIE that marks the Paleocene-Eocene Thermal Maximum. However, Sr-isotope evidence (McArthur et al., 2000), as well as recent estimates based on spectral analyses (Suan et al., 2008) suggest that the negative CIE spans at least 5-10 times that amount of time. Even more problematic evidence comes from C-isotope records derived from belemnite calcite. The absence of a negative CIE in low-Mg-calcite belemnite rostra (van de Schootbrugge et al., 2005b; Gomez et al., 2008) contradicts a global perturbation in all carbon reservoirs. It thus appears that the negative Toarcian CIE is more adequately explained by the Küspert-model (Küspert, 1982), which takes into account the recycling of ${ }^{12} \mathrm{C}$-enriched $\mathrm{CO}_{2}$ from the lower layers of a stratified euxinic water column (Saelen et al., 1998; Saelen et al., 2000). The Küspert-model also supports the notion that a low salinity cap, as shown by oxygen isotope and $\mathrm{Mg} / \mathrm{Ca}$ records from belemnites .(Bailey et al., 2003; Rosales et al., 2001; Rosales et al., 2004a; Rosales et al., 2004b; van de Schootbrugge et al., 2005a), decreased in importance from the humid Boreal to the arid Tethyan region. The establishment of a stable pycno- and chemocline during the H. falciferum Zone is corroborated by the presence of abundant molecular fossils derived from phototrophic green sulfur bacteria (Frimmel et al., 2004; Pancost et al., 2004; Schouten et al., 2000; van Breugel et al., 2005), that require both light and $\mathrm{H}_{2} \mathrm{~S}$.

Hydrocarbon and/or methane seepage is undeniably an important process on the modern sea floor and is increasingly being recognized to fuel Recent chemosynthetic ecosystems, for example in the Gulf of Mexico (Campbell, 2006). Over the past 10 years, the occurrence of methane cold seeps and hydrocarbon expulsion has unequivocally been demonstrated in Devonian, Carboniferous, Jurassic and Cenozoic 
sediments (Peckmann et al., 1999a; Peckmann et al., 1999b Goedert et al., 2000; Aiello et al., 2001; Peckmann et al., 2001; Goedert et al., 2003; Peckmann et al., 2007; Himmler et al., 2008). In part such systems can be shown to have been fueled by thermogenic methane that is advected from deep lying reservoirs. Linking paleoseeps to the destabilization of clathrates has been extremely difficult. To this comes that estimates of the volume of present-day clathrates occurring on shelfs around the globe vary considerably (Dickens, 2003; Milkov, 2004), which seriously complicates calculation of their volume in the geological past. Despite such uncertainties, a 7\%o negative CIE for the Toarcian OAE would require the simultaneous release of several times the entire present-day reservoir.

Some isolated occurrences of seep deposits have been reported from the Lower Jurassic in Argentina. Gomez-Perez (2003) described tube-worm carbonate bioherms from the largely siliciclastic Los Molles Fm that show similarities to modern cold seep bioherms. Available ammonite biostratigraphy indicates an uppermost Pliensbachian to lowermost Toarcian age for these bioherms Allison et al. (2008) and Price et al. (2008) investigated conical carbonate structures, akin to small mud-mounds, from the Upper Sinemurian of SW England, which bear carbon isotope signatures of methane seepage, making this effectively the oldest Mesozoic cold seep occurrence. In accord with uniformitarian principles, methane seepage was thus likely also a common process on the Jurassic sea floor. Whether the occurrence of Tisoa siphonalis concretions in the Upper Pliensbachian across northern and southern France is of significance for the debate on the Toarcian C-isotope excursion remains to be seen. What is clear is that boundary conditions that led to the Toarcian OAE were set during the latest Pliensbachian.

\section{Conclusions}

We have provided a new interpretation of the enigmatic trace fossil Tisoa siphonalis DE SERRES 1840 and discussed the larger ramifications of our findings. Based on sedimentological observations, stable isotope analyses, and computer tomographic scanning, we can show that tubular carbonate concretions have strongly depleted $\delta^{13} \mathrm{C}$ values and contain multiple, pyrite-filled canals, not just 2 central canals as was previously thought. Our results clearly suggest that Tisoa siphonalis is abiogenic in nature and was the result of authigenic carbonate deposition in the sedimentary pile due to the combined process of anaerobic methane oxidation and sulfate reduction. As such, T. siphonalis is similar to other occurrences of subsurface conduits linked to the mobilization of fluids rich in hydrocarbons. A literature survey shows that these tubular authigenic carbonate concretions are widespread in the Grands Causses Basin in southern France, occurring exclusively in the Upper Pliensbachian Gibbosus Subzone of the Margaritatus Zone. Similar concretions have also been described from the region around Metz and Bettembourg, in Northern France and Luxemburg, respectively. Because of this widespread occurrence, fault related mobilization of fluids during large-scale geodynamic processes, such as pulsed spreading in the Tethys, becomes unlikely as a mechanism. We favour a scenario that takes into account a major eustatic sea level lowering during the latest Pliensbachian concurrent with a strong decrease in sedimentation rates and/or (submarine) erosion. The latest Pliensbachian is known to have been a colder interval, but the exact nature of these events, particularly in relation to build-up of icecaps during the Late Pliensbachian, and to the deposition of Toarcian black shales, requires further research. Future avenues should include the study of monospecific brachiopod bioherms and hardgrounds in the Late Pliensbachian, analysis of sulfur isotopes, detailed organic geochemistry, and trace element analyses, in order to constrain intensity, duration, and type of hydrocarbon seepage.

\section{Supplementary material related to this article is available online at: http://www.biogeosciences.net/7/3123/2010/ bg-7-3123-2010-supplement.pdf.}

Acknowledgements. The authors wish to thank Eckehard Gottwald and Renald Gless for their help with preparation of the samples. The reviewers Aurelien Gay and Philippe Leonide are thanked for providing constructive reviews. Permission to access the outcrops at Truc-de-Balduc was generously provided by the mayor of St.-Bauzile, and at Fressac by Bill and Estelle Homewood. KS and $\mathrm{DH}$ acknowledge financial support for carrying out fieldwork in southern France from the Freunden \& Förderer Foundation and the Wilkommen Foundation.

Edited by: W. Kiessling

\section{References}

Aiello, I. W.: Fossil seep structures of the Monterey Bay region and tectonic/structural controls on fluid flow in an active transform margin, Palaeogeogr. Palaeoclim. Palaeoecol., 227, 124 $142,2005$.

Aiello, I. W., Garrison, R. E., Moore, J. C., Kastner, M., and Stakes, D. S.: Anatomy and origin of carbonate structures in a Miocene cold-seep field, Geology, 29, 1111-1114, 2001.

Allison, P. A., Hesselbo, S. P., and Brett, C. E.: Methane seeps on an Early Jurassic dysoxic seafloor, Palaeogeogr. Palaeoclim. Palaeoecol., 270, 230-238, 2008.

Andree, K.: Bedeutung und zeitliche Verbreitung von Arenicoloides Blanckenhorn und verwandten Formen, Paläont. Zt, 8, 120-128, 1927.

Arndt, S., Hetzel, A., and Brumsack, H.-J.: Evolution of organic matter degradation in Cretaceous black shales inferred from authigenic barite: A reaction-transport model, Geochim. Cosmochim. Ac., 73, 2000-2022, 2009. 
Bailey, T. R., Rosenthal, Y., McArthur, J. M., van de Schootbrugge, B., and Thirlwall, M. F.: Paleoceanographic changes of the Late Pliensbachian-Early Toarcian interval: a possible link to the genesis of an Oceanic Anoxic Event, Earth Planet. Sci. Lett., 212, 307-320, 2003.

Bather, F. A.: Tisoa siphonalis Marcel de Serres, a supposed liassic annelid, Naturalist, 7-10, 1924.

Bertling, M., Braddy, S. J., Bromley, R. G., Demathieu, G. R., Genise, J., Mikulas, R., Nielsen, J. K., Nielsen, K. S. S., Rindsberg, A. K., Schlirf, M., and Uchman, A.: Names for trace fossils: a uniform approach, Lethaia, 39, 265-286, 2006.

Bleicher, M. G.: Guide du Géologue en Lorraine, Meurthe-etMoselle, Vosges, Meuse, Berger-Levrault, Paris, 1887.

Campbell, K. A.: Hydrocarbon seep and hydrothermal vent paleoenvironments and paleontology, Past developments and future research directions, Palaeogeogr. Palaeoclim. Palaeoecol., 232, 362-407, 2006.

Campbell, K. A., Francis, D. A., Collins, M., Gregory, M. R., Nelson, C. S., Greinert, J., and Aharon, P.: Hydrocarbon seepcarbonates of a Miocene forearc (East Coast Basin), North Island, New Zealand. Sed. Geol., 204, 83-105, 2008.

Cassel, Y.: Évolution géodynamique de la marge cévenole entre Saint-Ambroix et Anduze (Gard Septentrional) de l'Hettangien au Bajocien inferieur, Doc. Lab. Geol., Lyon, 144, pp 312, 1997.

Cavagna, S., Clari, P., and Martire, L.: The role of bacteria in the formation of cold seep carbonates: geological evidence from Monferrato (Tertiary, NW Italy), Sed. Geol., 126, 253-270, 1999.

Chenu, J. C.: Manuel de conchyliologie et de paléontologie conchyliologique, 1, Paris, 1859.

Clauer, N., Zwingmann, H., and Chaudhuri, S.: Isotopic (K-Ar and oxygen) constraints on the extent and importance of the Liassic hydrothermal activity in western Europe, Clay Min., 31, 301318, 1996.

Dera, G., Pucéat, E., Pellenard, P., Neige, P., Delsate, D., Joachimski, M. M., Reisberg, L., and Martinez, M.: Water mass exchange and variations in seawater temperature in the NW Tethys during the Early Jurassic: evidence from neodymium and oxygen isotopes of fish teeth and belemnites, Earth Planet. Sci. Lett., 286, 198-207, 2009a.

Dera, G., Pellenard, P., Neige, P., Deconinck, J.-F., Pucéat, E., and Dommergues, J.-L.: Distribution of clay minerals in Early Jurassic Peritethyan seas: palaeoclimatic significance inferred from multiproxy comparisons, Palaeogeogr., Palaeoclim., Palaeoecol., 271, 39-51, 2009b.

De Boever, E., Swennen, R., and Dimitrov, L.: Lower Eocene carbonate cemented chimneys (Varna, NE Bulgaria): Formation mechanisms and the (a)biological mediation of chimney growth, Sed. Geol., 185, 159-173, 2006.

de Brun, P. and Brousse, M.: Le Lias de Valz près de Ales (Gard), Trav. Lab. Geol. Fac. Sci., Lyon, 32, 1-68, 1936.

de Serres, M.: Description de quelques mollusques fossiles nouveaux des terrains infra-liassiques et de la craie compacte inférieure du Midi de la France, Ann. Sci. Nat.(Zoologie), 14, 5-25, 1840 .

de Serres, M.: De quelques mollusques nouveaux, des terrains infra-jurassiques et de la craie compacte inférieure du Midi de la France, Actes Soc. linnéenne Bordeaux, 39, 83-109, 1842.

Diaz-del-Rio, V., Somoza, L., Martinez-Frias, J., Mata, M. P.,
Delgado, A., Hernandez-Molina, F. J., Lunar, R., MartinRubi, J. A., Maestro, A., Fernandez-Puga, M. C., Leon, R., Llave, E., Medialdea, T., and Vazquez, J. T.: Vast fields of hydrocarbon-derived carbonate chimneys related to the accretionary wedge/olistostrome of the Gulf of Cadiz, Mar. Geol., 195, 177-200, 2003.

Dickens, G. R.: Rethinking the global carbon cycle with a large, dynamic and microbially mediated has hydrate capacitor, Earth Planet. Sci. Lett., 213, 169-183, 2003.

Dumont, T.: Late Triassic-Early Jurassic evolution of the western Alps and of their European foreland - Initiation of the Tethyan rifting, Bull. Soc. Geol. France, 4, 601-611, 1988.

Dumortier, E.: Lias-Moyen. Études paléontologiques sur les dépôts jurassiques du Bassin du Rhône, 3, 173-188, 1869.

Fiebig, J., Schöne, B. S., and Oschmann, W.: High-precision oxygen and carbon isotope analysis of very small $(10-30 \mathrm{mg})$ amounts of carbonates using continuous flow isotope ratio mass spectrometry, Rapid Comm. Mass Spec., 19, 2355-2358, 2005.

Frey, R. W. and Cowles, J. G.: The trace fossil Tisoa in Washington and Oregon, The Ore Bin, 34, 113-119, 1972.

Freytag, J. K., Girguis, P. R., Bergquist, D. C., Andras, J. P., Childress, J., and Fisher, C. R.: A paradox resolved: Sulfide acquisition by roots of seep tubeworms sustains net chemoautotrophy, Proc. Nat. Acad. Sci., 98, 13408-13413, 2001.

Frimmel, A., Oschmann, W., and Schwark, L.: Chemostratigraphy of the Posidonia Black Shale, SW Germany I. Influence of sealevel variation on organic facies evolution, Chem. Geol., 206, 199-230, 2004.

Friren, A.: Mélanges paléontologiques. 1er article: Orthoidea, Straparolus, Ammonites, Aulacoceras \& Tisoa siphonalis du Lias Moyen, Bull. Soc. Hist. Nat. Metz, 14, 1-21, 1876.

Friren, A.: Mélanges paléontologiques. IIe article: Faune fossile de Bevoie (Lias moyen), Observation sur quelques brachiopodes très rares. Histoire de deux fossiles, Note sur le Tisoa siphonalis, Bull. Soc. Hist. Nat. Metz, 17, 3-80, 1887.

Gay, A., Takano, Y., Gilhooly III, W. P., Berndt, C., Heeschen, K., Suzuki, T., Saegusa, S., Nakagawa, F., Tsunogai, U., Jiang, S. Y., and Lopez, M.: Geophysical and geochemical evidence of large scale fluid flow within shallow sediments in the eastern Gulf of Mexico, offshore Louisiana, Geofluids, doi:10.1111/j.14688123.2010.304.x, 2-14, 2010.

Goedert, J. L., Peckmann, J., and Reitner, J.: Worm tubes in an allochtonous cold-seep carbonate from Lower Oligocene rocks of western Washington, J. Paleont., 74, 992-999, 2000.

Goedert, J. L., Thiel, V., Schmale, O., Rau, W. W., Michaelis, W., and Peckmann, J.: The Late Eocene Whiskey Creek methane-seep deposit (Western Washington State) Part I: Geology, palaeontology, and molecular geobiology, Facies, 48, 223 240, 2003.

Gomez, J. J., Goy, A., and Canales, M. L.: Seawater temperature and carbon isotope variations in belemnites linked to mass extinction during the Toarcian (Early Jurassic) in Central and Northern Sapin. Comparison with other European sections, Palaeogeogr. Palaeoclim. Palaeoecol., 258, 28-58, 2008.

Gomez-Perez, I.: An Early Jurassic deep-water stromatolitic bioherm related to possible methane seepage (Los Molles Formation, Neuquen, Argentina), Palaeogeogr. Palaeoclim. Palaeoecol., 201, 21-49, 2003.

Gottis, C.: Sur un Tisoa très abondants dans le Numidien de Tunisie, 
Bull. Soc. Sci. Nat. Tunisie, 7, 184-195, 1954.

Guex, J., Morard, A., Bartolini, A., and Morettini, E.: Découverte d'une importante lacune stratigraphique à la limite DomérienToarcien: implications paléo-océanographiques, Bull. Soc. Vaudois Sci. Nat., 87, 277-284, 2001.

Haas, A., Little, C. T. S., Sahling, H., Bohrmann, H., Himmler, T., and Peckmann, J.: Mineralization of vestimentiferan tubes at methane seeps on the Congo deep-sea fan, Deep-Sea Res. Pt. I, doi:10.1016/j.dsr.2008.08.007, 283-293, 2009.

Hänztschel, W. (Editor) Part W, Miscellanea, supplement 1. Trace fossils and problematica. Treatise on invertebrate paleontology. Geological Society of America/University of Kansas Press, Boulder, Lawrence, 1975.

Harazim, D., van de Schootbrugge, B., Sorichter, K., Fiebig, J., Weug, A., Suan, G., and Oschmann, W.: Spatial variability in watermass conditions in the European Epicontinental Seaway during the Pliensbachian and Toarcian, in preparation, 2010.

Hendry, J. P., Paerson, M. J., Trewin, N. H., and Fallicks, A. E.: Jurassic septarian concretions fromm NW Scotland record interdependent bacterial, physical and chemical processes of marine mudrock diagenesis, Sediment., 53, 537-565, 2006.

Henry, B., Rouvier, H., le Goff, M., Leach, D., Macquar, J.-C., Thibieroz, J., and Lewchuk, M. T.: Palaeomagnetic dating of widespread remagnetization on the southeastern border of the French Massif Central and implications for fluid flow and Mississippi Valley-type mineralization, Geophys. J. Inter., 145, 368380, 2001.

Hermoso, M., Le Callonnec, L., Minoletti, F., Renard, M., and Hesselbo, S. P.: Expression of the Early Toarcian negative carbonisotope excursion in separated microfractions (Jurassic, Paris Basin), Earth Planet. Sci. Lett., 277, 194-203, 2009.

Hesselbo, S. P., Gröcke, D. R., Jenkyns, H. C., Bjerrum, C. J., Farrimond, P., Morgans Bell, H. S., and Green, O. R.: Massive dissociation of gas hydrate during a Jurassic oceanic anoxic event, Nature, 406, 392-395, 2000.

Hesselbo, S. P., Jenkyns, H. C., Duarte, L. V., and Oliveira, L. C. V.: Carbon isotope record of the Early Jurassic (Toarcian) Oceanic Anoxic Event from fossil wood and marine carbonate (Lusitanian Basin, Portugal), Earth Planet. Sci. Lett., 253, 455-470, 2007.

Himmler, T., Freiwald, A., Stollhofen, H., and Peckmann, J.: Late Carboniferous hydrocarbon-seep carbonates from the glaciomarine Dwyka Group, southern Namibia, Palaeogeogr. Palaeoclim. Palaeoecol., doi:10.1016/j.palaeo.2007.09.018, 185-197, 2008.

Jenkyns, H. C.: The early Toarcian (Jurassic) anoxic event: stratigraphic, sedimentary, and geochemical evidence, Am. J. Sci., 288, 101-151, 1988.

Jenkyns, H. C. and Clayton, C. J.: Lower Jurassic epicontinental carbonates and mudstones from England and Wales: chemostratigraphic signals and the early Toarcian anoxic event, Sediment., 44, 687-706, 1997.

Jenkyns, H. C. and Clayton, C. J.: Black shales and carbon isotopes in pelagic sediments from the Tethyan Lower Jurassic, Sediment., 33, 87-106, 1986.

Kemp, D. B., Coe, A. L., Cohen, A. S., and Schwark, L.: Astronomical pacing of methane release in the Early Jurassic period, Nature, 437, 396-399, 2005.

Kiel, S.: Global hydrocarbon seep-carbonate precipitation correlates with deep-water temperatures and eustatic sea-level fluctu- ations since the Late Jurassic, Terra Nova, 21, 279-284, 2009.

Küspert, W.: Environmental change during oil shale deposition as deduced from stable isotope ratios, in: Cyclic and event stratification, edited by: Einsele, S., Springer-Verlag, 482-501, 1982.

Lash, G. G. and Blood, D.: Geochemical and textural evidence for early (shallow) diagenetic growth of stratigraphically confined carbonate concretions, Upper Devonian Rhinestreet black shale, western New York, Chem. Geol., 206, 407-424, 2004.

Lemoine, M. and de Graciansky, P. C.: History of a passive continental-margin - The Western Alps in the Mesozoic, Bull. Soc. Geol. France, 4, 597-600, 1988.

Leonide, P., Floquet, M., and Villier, L.: Interactions of tectonics, eustasy, climate and carbonate production on the sedimentary evolution of an early/middle Jurassic extensional basin (Southern Provence Sub-basin, SE France), Basin Res., 19, 125-152, 2007.

Lessertisseur, J.: Traces fossiles d'activité animale et leur signification paléobiologique, Soc. geol. France, Memoir N.S. 74, 1-150, 1955.

Louis-Schmidt, B., Rais, P., Logvinovich, D., Bernasconi, S. M., and Weissert, H.: Impact of methane seeps on the local carbonisotope record: a case study from a Late Jurassic hemipelagic section, Terra Nova, 19, 259-265, 2007.

Mattei, J.: Le brachyanticlinal du Pic Saint-Loup (Hérault, BasLanguedoc), Extrait de Géologie de la France, BRGM, 4, 349376, 1986.

Maubeuge, P. L.: Notes paléontologiques. III. Sur la nature végétale probable d'Ancyloceras mosellense TERQUEM et de Tisoa siphonalis M. de SERRES, Bull. Soc. Sci. Nancy N.S., 11, 4648, 1947.

McArthur, J. M.: Comment on "Carbon-isotope record of the Early Jurassic (Toarcian) Oceanic Anoxic Event from fossil wood and marine carbonate (Lusitanian Basin, Portugal)" edited by: Hesselbo, S., Jenkyns, H. C., Duarte, L. V., Oliveira, L. C. V., Earth Planet. Sci. Lett., 259, 634-639, 2007.

McArthur, J. M., Algeo, T. J., van de Schootbrugge, B., Li, Q., and Howarth, R. J.: Basinal restriction, black shales, Re-Os dating, and the Early Toarcian (Jurassic) oceanic anoxic event, Paleocean., 23, PA4217, doi:10.1029/2008PA001607, 2008.

McArthur, J. M., Donovan, D. T., Thirlwall, M. F., Fouke, B. W., and Mattey, D.: Strontium isotope profile of the early Toarcian (Jurassic) oceanic anoxic event, duration of ammonite biozones, and belemnite palaeotemperatures, Earth Planet. Sci. Lett., 179, 269-285, 2000.

McElwain, J. C., Wade-Murphy, J., and Hesselbo, S. P.: Changes in carbon dioxide during an oceanic anoxic event linked to intrusion into Gondwana coals, Nature, 435, doi:10.1038/nature03618, 479-482, 2005.

Mennessier, G., Astruc, J.-G., Bambier, A., Collomb, P., Galharague, J., and Roche, J.: Notice explicative de la feuille Millau à 1/50000, BRGM, Orleans, 1984.

Mennessier, G. and Collomb, P.: Notice explicative de la feuille Saint-Beauzely, BRGM, Orléans, 1986.

Merzeraud, G. and Colombie, C.: Évolution morphologique des profils de dépôts dans le Sinémurien de la marge cévenole (region de Lodeve), C.R. Acad. Sci. Paris/Earth Planet. Sci., 329, 779-786, 1999.

Milkov, A. V.: Global estimates of hydrate-bound gas in marine sediments: how much is really out there? Earth-Science Reviews, 
66, 183-197, 2004.

Morard, A.: Les événements du passage Domérien-Toarcien entre Tethys occidentale et Europe du Nord-Ouest, Université de Lausanne, Lausanne, 2004.

Morard, A., Guex, J., Bartolini, A., Morettini, E., and De Wever, P.: A new scenario for the Domerian-Toarcian transition, Bull. Soc. geol. France, 174, 351-356, 2003.

Newton, R. and Bottrell, S.: Stable isotopes of carbon and sulphur as indicators of environmental change: past and present, J. Geol. Soc. London, 164, 691-708, 2007.

Nyman, S. L., Nelson, C. S., and Campbell, K. A.: Miocene tubular concretions in East Coast Basin, New Zealand: Analogue for the subsurface plumbing of cold seeps, Mar. Geol., doi:10.1016/j.margeo.2009.03.021, 319-336, 2009.

Pancost, R. D., Crawford, N., Magness, S., Turner, A., Jenkyns, H. C., and Maxwell, J. R.: Further evidence for the development of photic-zone euxinic conditions during Mesozoic oceanic anoxic events, J. Geol. Soc. London, 161, 353-364, 2004.

Pearson, M. J., Hendry, J. P., Taylor, C. W., and Russell, M. A.: Fatty acids in sparry calcite fracture fills and microsparite cement of septarian diagenetic concretions, Geochim. Cosmochim. Ac., 69, 1773-1786, 2005.

Pearson, M. J. and Nelson, C. S.: Organic geochemistry and stable isotope composition of New Zealand carbonate concretions and calcite fracture fills, New Zealand, J. Geol. Geophys., 48, 395414, 2005

Peckmann, J., Campbell, K. A., Walliser, O. H., and Reitner, J.: A Late Devonian hydrocarbon-seep deposit dominated by dimerelloid brachiopods, Morocco, Palaios, 22, 114-122, 2007.

Peckmann, J., Gischler, E., Oschmann, W., and Reitner, J.: An Early Carboniferous seep community and hydrocarbon-derived carbonates from the Harz Mountains, Germany, Geology, 29, 271-274, 2001

Peckmann, J., Thiel, V., Michaelis, W., Clari, P., Gaillard, C., Martire, L., and Reitner, J.: Cold seep deposits of Beauvoisin (Oxfordian; southeastern France) and Marmorito (Miocene; northern Italy), microbially induced authigenic carbonates, Int. J. Earth Sci., 88, 60-75, 1999a.

Peckmann, J., Walliser, O. H., and Riegel, W.: Signature of hydrocarbon venting in a middle Devonian carbonate mound (Hollard Mound) at the Hamar Laghdad (Anti-Atlas, Morocco), Facies, 40, 281-296, 1999b.

Pierre, C. and Fouquet., Y.: Authigenic carbonates from methane seeps of the Congo deep-sea fan, Geo-Mar. Lett., 27, 249-257, 2007.

Pierre, C. and Rouchy, J.-M.: Isotopic compositions of diagenetic dolomites in the Tortonian marls of the western Mediterranean margins: evidence of past gas hydrate formation and dissociation, Chem. Geol., 205, 469-484, 2004.

Price, G. D.: The evidence and implications of polar ice during the Mesozoic, Earth-Sci. Rev., 48, 183-210, 1999.

Price, G. D., Vowles-Sheridan, N., and Anderson, M. W.: Lower Jurassic mud volcanoes and methane, Kilve, Somerset, UK., Proc. Geol. Assoc., 119, 193-201, 2008.

Raiswell, R. and Fisher, Q. J.: Rates of carbonate cementation associated with sulphate reduction in DSDP/ODP sediments: Implications for the formation of concretions, Chem. Geol., 211, 71-85, 2004.
Razin, P., Bonijoly, D., Le Strat, P., Courel, L., Poli, E., Dromart, G., and Elmi, S.: Stratigraphic record of the structural evolution of the western extensional margin of the Subalpine Basin during the Triassic and Jurassic, Ardèche, France, Mar. Petrol. Geol., 13, 625-652, 1996.

Rosales, I., Quesada, S., and Robles, S.: Primary and diagenetic isotopic signals in fossils and hemipelagic carbonates: the Lower Jurassic of northern Spain, Sediment, 48, 1149-1169, 2001.

Rosales, I., Quesada, S., and Robles, S.: Paleotemperature variations of Early Jurassic seawater recorded in geochemical trends of belemnites from the Basque-Cantabrian basin, northern Spain, Palaeogeogr., Palaeoclim., Palaeoecol., 203, 253-275, 2004a.

Rosales, I., Robles, S., and Quesada, S.: Elemental and oxygen isotope composition of Early Jurassic belemnites: Salinity versus temperature signals, J. Sed. Res., 74, 342-354, 2004 b.

Rouvier, H., Henry, B., Macquar, J.-C., Leach, D. L., Le Goff, M., Thibieroz, J., and Lewchiuk, M. T.: Réaimantation régionale eocène, migration de fluides et minéralisations sur la bordure cévenole (France), Bull. Soc. Geol. France, 172, 503-516, 2001.

Saelen, G., Doyle, P., Talbot, M. R., and Telnaes, N.: Evidence for recycling of isotopically light $\mathrm{CO}_{2(a q)}$ in stratified black shale basins: Contrasts between the Whitby Mudstone and Kimmeridge Clay Formations, United Kingdom, Geology, 26, 747750, 1998.

Saelen, G., Tyson, R. V., Telnaes, N., and Talbot, M. R.: Contrasting watermass conditions during deposition of the Whitby Mudstone (Lower Jurassic) and Kimmeridge Clay (Upper Jurassic) formations, UK., Palaeogeogr., Palaeoclim., Palaeoecol., 163, 163-196, 2000.

Schellenberg, F.: The Paramoudra concretions within the Urenui Formation, Taranaki Basin, west coast of New Zealand. Diploma thesis, University of Tübingen, Tübingen, 58 pp., 2002.

Schouten, S., van Kaam-Peters, M. E., Rijpstra, I., Schoell, M., and Sinnighe Damste, J. S.: Effects of an oceanic anoxic event on the stable carbon isotopic composition of early Toarcian carbon, Am. J. Sci., 300, 1-22, 2000.

Spoetl, C. and Vennemann, T. W. Continuous-flow isotope ratio mass spectrometric analysis of carbonate minerals, Rapid Comm. Mass Spec., 17, 1004-1006, 2003.

Stchepinsky, V.: Le Lias de Durfort (Gard), Bull. Soc. Geol. France, 17, 593-615, 1937.

Suan, G., Pittet, B., Bour, I., Mattioli, E., Duarte, L. V., and Mailliot, S.: Duration of the Early Toarcian carbon isotope excursion deduced from spectral analysis: consequence for its possible causes, Earth Planet. Sci. Lett., 267, 666-679, 2008.

Svensen, H., Planke, S., Chevallier, L., Malthe-Sorenssen, A., Corfu, F., and Jamtveit, B.: Hydrothermal venting of greenhouse gases triggering Early Jurassic global warming, Earth Planet. Sci. Lett., 256, 554-566, 2007.

Teichert, B. M. A, Eisenhauer, A., Bohrmann, G., Haase-Schramm, A., Bock, B., and Linke, P.: U/Th systematics and ages of authigenic carbonates from Hydrate Ridge, Cascadia Margin: Records of fluid flow variations, Geochim. Cosmochim. Ac., 67, 3845-3857, 2003.

Trümpy, D. M.: Le Lias moyen et supérieur des Grands Causses et de la région de Rodez; contributions stratigraphiques, sédimentologiques et géochimiques à la connaissance d'un bassin à sédimentation marneuse, University of Zürich, Zürich, 363 pp., 1983. 
van Breugel, Y., Schouten, S., Paetzel, M., Nordeide, R., and Sinninghe-Damste, J. S.: The impact of recycling of organic carbon on the stable carbon isotopic composition of dissolved inorganic carbon in a stratified marine system (Kyllaren Fjord, Norway), Organic Geochem., 36, 1163-1174, 2005.

van de Schootbrugge, B., Bailey, T. R., Rosenthal, Y., Katz, M., Wright, J. D., Feist-Burkhardt, S., Miller, K. G., and Falkowski, P. G.: Early Jurassic climate change and the radiation of organicwalled phytoplankton in the Tethys Ocean, Paleobiol., 31, 73-97, 2005a.

van de Schootbrugge, B., McArthur, J. M., Bailey, T. R., Rosenthal, Y., Wright, J. D., and Miller, K. G.: Toarcian oceanic anoxic event: Assessment of global causes using belemnite C-isotope records, Paleocean., 20, PA3008, doi:10.1029/2004PA001102, 2005b.
Wignall, P. B. and Bond, D. P. G.: The end-Triassic and Early Jurassic mass extinction records in the British Isles, Proc. Geol. Assoc., 119, 73-84, 2008.

Wignall, P. B., Newton, R. J., and Little, C. T. S.: The timing of paleoenvironmental change and cause-and-effect relationships during Early Jurassic mass extinction in Europe, Am. J. Sci., 305, 1014-1032, 2005.

Wignall, P. B., McArthur, J. M., Little, C. S. T., and Hallam, A.: Methane release in the Early Jurassic period, Nature, 441, E5E6, 2006. 